\title{
The Use of Bokashi Compost as a Soil Fertility Amendment in Increasing Vegetative Growth of Organic Tomato (Lycopersicum Esculentum Mill.)
}

\author{
Selvia Dewi Pohan ${ }^{1}$, Amrizal $^{2}$, Eli Masni ${ }^{3}$, Wina Dyah Puspitasari ${ }^{4}$, Nuraisah Malau ${ }^{5}$, \\ Reninda Pasaribu ${ }^{6}$, Rahmayani Siregar ${ }^{7}$ \\ \{selviadewipohan@unimed.ac.id ${ }^{1}$ \} \\ Biology Department, Faculty of Mathematics and Natural Sciences, Universitas Negeri Medan ${ }^{1}$, \\ Biology Department, Faculty of Mathematics and Natural Sciences, Universitas Sumatera Utara \\ Jln. Bioteknologi, Padang Bulan, Medan Baru, Kota Medan, Indonesia $20155^{2}$ and Chemistry \\ Department, Faculty of Mathematics and Natural Sciences, Universitas Negeri Medan \\ Jln. Willem IskandarPsr V, Medan Estate, Medan, Indonesia $20221^{3,4,5,6,7}$
}

\begin{abstract}
Bokashi holds the promise of a solution for wastes problem, because of its ability to turnover of organic wastes fastly, requiring less land and equipment. The study about the effect of bokashi compost on vegetative growth of tomato (Lycopersicum esculentum Mill.) was conducted to determine the nutrition content of bokashi compost made from traditional market wastes and to investigate its effect on tomato's vegetative growth. Some growth parameters such as plant's height and leaf's number were measured per week, while stem's diameter and branch number were measured in third and sixth week after cultivation, root lenght and fresh weight was measured in eight weeks after cultivation. Investigation of the effect of bokashi compost fertilizer on tomato's vegetative growth using an experimental method by using a Completely Randomized Design with 4 treatments and six repetitions. The treatments were bokashi compost fertilizer with 4 levels of dose, namely control (no fertilizer), $2.5 \mathrm{~kg}$ (soil:fertilizer rasio 1:1), $1.67 \mathrm{~kg}$ (soil:fertilizer rasio 2:1), and $1.25 \mathrm{~kg}$ (soil:fertilizer rasio 3:1). The obtained data was analyzed using one way ANOVA then continued with Duncan posthoc test. The study results indicated that bokashi compost consists of $0.43 \%$ Nitrogen, 2.15\% Phospate $\left(\mathrm{P}_{2} \mathrm{O}_{5}\right), 2.68 \%$ Potassium $\left(\mathrm{K}_{2} \mathrm{O}\right)$ and $43.4 \%$ of moisture content. According to the observation towards the bokashi compost effect on tomato's growth, revealed that the fertilizer has significant effect on plant growth. Statistical analysis evidenced that bokashi compost with dose $1.67 \mathrm{~kg}$ is the best treatment for tomato's vegetative growth.
\end{abstract}

Keywords: bokashi, compost, soil fertility, vegetative growth, organic tomato

\section{Introduction}

Farmers in North Sumatra were applied chemical fertilizers and sinthetic pesticides to ignore plant's pests and diseases. Eventhough the price was increased significantly, pesticides still be considered to be the most effective and simple materials to solve these problems. Several studies had been evidenced negative effects of chemical pesticides, such as pest's resistance, overpopulation of new pest, accumulation of pesticides residues, environment pollution, harmful to humanlife and healthy, and damaging of ecosystem balance (Catillo et al, 
2010). The study about environmental hazards associated with pesticide by Castillo et al., (2014) revealed that pesticides using caused aquatic contamination in Costa Rica, quantity of pesticides capable of reaching water bodies increased during analysis period, $98 \%$ of the pesticides were classified as acutely toxic for fish and crustaceans and $73 \%$ for amphibians. Approximately, $8.4 \mathrm{~kg}$ of active ingredients were imported per hectare of protected areas and $24.3 \mathrm{~kg}$ of active ingredients per hectare of wetlands.

Chaturvedi, Sharma and Chaturvedi (2013) also said that pesticides can cause harm to humans, animals, or the environment because they are designed to bill adversely affect living organisms. Pesticides are airborne so that they can found long distances from the site of application, exposure of wildlife over and extended period of time to pesticide may result in chronic poisoning.

Using of chemical fertilizer may causes compaction layer and soil degradation in longterm (root developments and plant growth will be limited) (Massah\& Azadegan, 2016). According to Rai et al. (2014) study, revealed that overuse of chemical fertilizers may decrease soil fertility, pollute air and water, release greenhouse gases, bring hazards to human's health and environment, kill soil friendly micro-organisms and earthworms. It also depletes essential soil nutrients and minerals that are naturally found in fertile soil. Furthermore, chemical fertilizers may cause root burn or fertilizer burn and do not allow enough water intake for the plants. It is also high in nitrogen salts, when $\mathrm{N}$ is absorbed by the soil too quickly, it will dehydrate and dry up the plant.

The use of organic materials on cultivation of vegetable and crops has many advantages for farmers, particularly in maintaining suitable soil conditions and decreasing utilization of chemical fertilizers. Nowaday, fertilizer from organic materials has been used worldwide, such as manure, compost, microbial fertilizer, etc. The positive effects of the use of these kind of fertilizers had been publised (Berova et al., 2010; Khanom et al. 2012; Jigme et al., 2015; Soeparjono, 2015; Sigit, 2016; Zerihun and Haile, 2017). Bokashi holds the promise of a solution for wastes problem, because of its ability to turnover of organic wastes fastly, requiring less land and equipment.

\section{Material And Method}

\subsection{Preparation of Bokashi Bran}

$5 \mathrm{~L}$ bucket was prepared. Mix bran, $200 \mathrm{~g}$ of brown sugar, $20 \mathrm{~mL}$ of EM4 and $3 \mathrm{~L}$ of water were mixed in to the bucket. The bucket was closed tightly and incubated for 3 days. The bokashi bran prepared was bownish clots with humidity approximately $40-60 \%$. This bokashi bran would be used for starter to the bokashi materials.

\subsection{Fermentation}

A layer of bokashi bran was sprinkled in the bottom of bucket. The amount of $20 \mathrm{~kg}$ vegetable scraps (in small pieces) was added in to the bucket, then covered it with the bokashi bran layer, for removing the air in the bucket and the mixture was pressed down using the "mid lid". It was repeated until the bucket full and the bucket lid was closed tightly. The mixture in the closed bucket then fermented for two weeks and not allowed to open during fermentation process. 


\subsection{Decomposition Process}

Decomposition process was carried out in outdoor by digging a hole about $50 \mathrm{~cm}$ depth. The bokashi bucket was poured into the hole and then the hole was covered to prevent animal to dig it up. The decomposition process was took for 2 weeks and ready to use.

\subsection{The Application of Bokashi on Tomato}

Observation the influence of the bokashi on tomato growth was measured by using a Completely Randomized Design consisted of four treatments and six repetitions. The treatments of bokashi fertilizers application as soil amandment with ratio of soil:bokashi were 1:1 (2.5 kg/polybag), 2:1 (1.67 kg/polybag), and 3:1 (1.25 kg/polybag) and control treatment (no bokashi).

The implementation of the research began with the nursery process; then the 1-week old seedlings were transferred to the treatment medium. Growth observations were conducted for eight weeks. The parameters measured to determine plant growth were as follows: (1) plant height; (2) number of leaves/plants; (3) stem diameter (4) bud number; (5) root length; and (6) plant fresh weight. The comparison of plant growth between treatments was analyzed by using one-way ANOVA (using SPSS 21 program) then continued with Duncan's Posthoc test at $\alpha=0.05$ level.

\section{Results And Discussion}

\subsection{The Composition of Bokashi Compost}

Before the bokashi was applied on the tomato, the composition analysis was measured to investigate the contain of nitrogen $(\mathrm{N})$, phosphorous $(\mathrm{P})$, and potassium $(\mathrm{K})$ concentration. The composition of bokashi was shown in the following Table 1.

Table 1. Modified Bokashi Compost Composition's Testing results

\begin{tabular}{clc}
\hline No. & \multicolumn{1}{c}{ Parameter } & Composition $(\%)$ \\
\hline 1. & Moisture Content & 43.4 \\
2. & Nitrogen $(\mathrm{N})$ & 0.43 \\
3. & Phosphate $\left(\mathrm{P}_{2} \mathrm{O}_{5}\right)$ & 2.15 \\
4 & Potassium $\left(\mathrm{K}_{2} \mathrm{O}\right)$ & 2.68
\end{tabular}

The bokashi contained a high of kalium (K) and phosphorus (P) content, but low concentration of nitrogen $(\mathrm{N})$ compared to cow manure. According to Syarief (1989), cow manure contained $0.6 \%$ of $\mathrm{N}, 0.15 \%$ of $\mathrm{P}_{2} \mathrm{O}_{5}$ and $0.45 \%$ of $\mathrm{K}_{2} \mathrm{O}$. But the bokashi content of $\mathrm{N}$, $\mathrm{P}, \mathrm{K}$ is lower than chicken manure. Chicken manure contained $2.2 \%$ of $\mathrm{N}, 2.9 \%$ of $\mathrm{P}_{2} \mathrm{O}_{5}$, and $2.1 \%$ of $\mathrm{K}_{2} \mathrm{O}$ (Hartatik and Setyorini, 2009).

Tomato growth was taken under greenhouse condition with temperature average was $32^{\circ} \mathrm{C}$ to $38^{\circ} \mathrm{C}$ and relative humidity was $42 \%$ to $66 \%$. Performance of tomato was influenced by different bokashi treatments. The following showed data results obtained after eight weeks of cultivation. 


\subsection{The Effect of Bokashi on Tomato's Growth}

The growth of tomato was highly influenced by applications of Bokashi. The plant's height rose consistently from the first week to the eighth week.

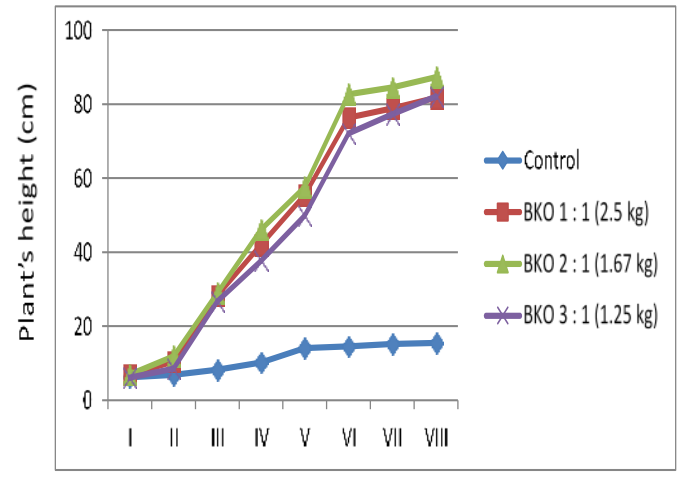

Week of observation

Fig. 1. The vegetative growth of tomato based on plant height $(\mathrm{cm})$ in all treatments during eight weeks of observation.

Bokashi also affected number of leaves significantly during the observation (Figure 2). Plants treated with bokashi is the tallest, as reported by El-Hamied (2014). In the following Figure 2 can be shown that the bokashi with ratio $3: 1$ was outstandingly influenced the number of leaves compared with another treatments. Number of leaves was increased rapidly during observation. The BKO 2:1 and 1:1 were also highly influenced the leaves number of plant compared to control treatment. The trend revealed that bokashi has positive impact on plant growth with 3:1 as the best treatment.

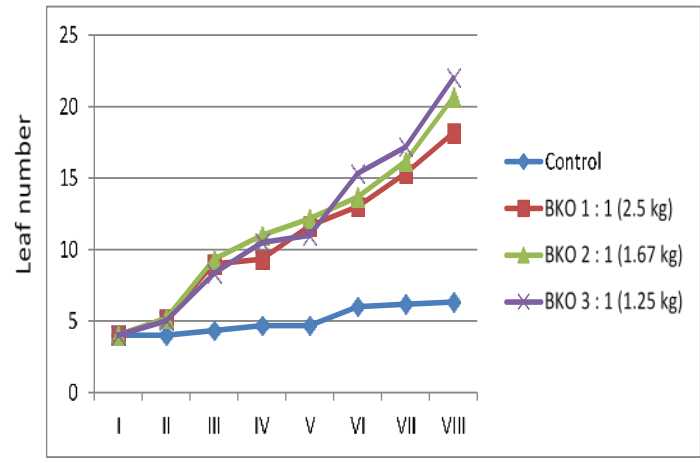

Week of observation

Fig. 2. The vegetative growth of tomato based on number of leaves (sheet) in all treatments during eight weeks of observation. 
Bokashi influenced tomato's growth significantly $(\mathrm{p}<0.05)$, particularly in treatments with dosage 2:1 and 3:1. Bokashi could provides nutrients for the plant and enriched soil with organic materials which helped by micro-organisms decomposition ability repaired soil structure and porosity. It also improved soil permeability, controlling secondary soil salinization (Xiaohou et al., 2008).

Bokashi with dosage 2:1 seen to be the appropriate concentration to increase plant height and leaves number. The formation of plant's leaves was strongly influenced by nutrients intake contained in the soil. With high content of $\mathrm{P}$ and $\mathrm{K}$, bokashi improved soil capability to supply nutrients for plant. Phosphorous is one of essential elements which function as a part of the nucleic acid backbone and it also has central function in intermediary metabolism. In addition, organic $\mathrm{P}$ is not available for uptake by plant, but it must be converted to an inorganic form first by micro-organism in the soil. While, potassium (K) activates enzymes (respiration and photosynthesis) and functions in osmoregulation. Furthermore, it also related to starch and protein synthesis. The high content of $\mathrm{P}$ and $\mathrm{K}$ in bokashi studied, soil properties could be improved and affected plant growth positively.

Table 2. Plant height $(\mathrm{cm})$ and leaves number of tomato in age 8 weeks old after cultivation (wac) in all treatments.

\begin{tabular}{clll}
\hline No & Treatments & $\begin{array}{c}\text { Plant's height } \\
(\mathrm{cm}) 8 \mathrm{wac}\end{array}$ & \multicolumn{1}{c}{$\begin{array}{c}\text { Leaves number } \\
\text { (sheet) } 8 \mathrm{wac}\end{array}$} \\
\hline 1 & $\begin{array}{l}\text { Control } \\
\text { (no bokashi) }\end{array}$ & $15.46 \pm 2.293^{\mathrm{a}}$ & $6.33 \pm 0.816^{\mathrm{a}}$ \\
2 & BKO 1:1 & $82.1 \pm 2.587^{\mathrm{b}}$ & $18.17 \pm 1.472^{\mathrm{b}}$ \\
3 & BKO 2:1 & $87.33 \pm 3.764^{\mathrm{c}}$ & $20.67 \pm 1.033^{\mathrm{c}}$ \\
4 & BKO 3:1 & $81.75 \pm 3.088^{\mathrm{b}}$ & $22 \pm 1.265^{\mathrm{c}}$ \\
\hline
\end{tabular}
0.05 .

Notes: Values followed by the same letter showed are not significantly different at at $\alpha=$

According to study result, stem diameter, branch number, root length and plant fresh weight were also highly influenced by the addition of bokashi $(\mathrm{p}<0.05)$. Plant structures were also related to the nutrients intake by plant. Based on the study, bokashi could supplies nutrients especially $\mathrm{N}, \mathrm{P}$, and $\mathrm{K}$, which are essential for plant in metabolic process. This result was also found by Christel and Gorres (2014) that evidenced the bokashi influence in spinach. The bokashi treatments had a more steady and prolonged supply of plant available nitrogen. The $\mathrm{C} / \mathrm{N}$ rasio influenced the activity of micro-organism in decomposition process. High content of $\mathrm{C} / \mathrm{N}$ rasio (more $\mathrm{C}$ than $\mathrm{N}$ ) caused competition between plants and micro-organism, there will be a lot of energy available for their formation and development. The low $\mathrm{C} / \mathrm{N}$ rasio indicates that decomposition process had properly (nitrification process goes well). However, the net nitrogen mineralization was also affected by incubation period. In this study, concentration of nitrogen was not too high that might be caused by the time of incubation process (2 weeks). Based on Boechat et al. (2013) revealed that wastes can enhanced organic matter degradation, resulting in quickly available quantity of net nitrogen.

The application of bokashi in this study proved to be very effective in improving plant's vegetative growth. This finding was also showned by several researches (Wijayanto et al., 
2016; Adel\&Hamied, 2014; Christel\&Gorres, 2014; Wasis\&Fathia, 2010). Based on the results it can be seen that EM-bokashi was suitable for vegetative growth of tomato, nutrients content of the bokashi could supplied nutrient needed by the plant. It also improved soil fertility, enriched soil with essential elements and environment friendly.

Table 3. Bokashi effect on stem diameter ( $\mathrm{mm})$, branch number, root length and plant fresh weight $(\mathrm{g})$ of tomato in age 6 and 8 weeks after cultivation (wac).

\begin{tabular}{clcccc}
\hline No & Treatments & $\begin{array}{c}\text { Stem diameter } \\
6 \text { wac }(\mathrm{mm})\end{array}$ & $\begin{array}{c}\text { Branch number } \\
8 \text { wac }\end{array}$ & $\begin{array}{c}\text { Root length } \\
\text { wac }(\mathrm{cm})\end{array}$ & $\begin{array}{c}\text { Fresh weight } 8 \\
\text { wac }(\mathrm{g})\end{array}$ \\
\hline 1 & $\begin{array}{l}\text { Control (no } \\
\text { bokashi) }\end{array}$ & $12.17 \pm 1.08^{\mathrm{a}}$ & $1.67 \pm 0.516^{\mathrm{a}}$ & $13.5 \pm 3.619^{\mathrm{a}}$ & $36.45 \pm 6.58^{\mathrm{a}}$ \\
2 & BKO 1:1 & $19.5 \pm 1.686^{\mathrm{b}}$ & $3.33 \pm 0.516^{\mathrm{b}}$ & $16.13 \pm 3.246^{\mathrm{b}}$ & $61.73 \pm 3.664^{\mathrm{b}}$ \\
3 & BKO 2:1 & $20.33 \pm 2.2^{\mathrm{b}}$ & $3.67 \pm 0.516^{\mathrm{b}}$ & $17.5 \pm 2.829^{\mathrm{c}}$ & $59.41 \pm 3.21^{\mathrm{b}}$ \\
4 & BKO 3:1 & $21.33 \pm 1.855^{\mathrm{b}}$ & $3.67 \pm 0.516^{\mathrm{b}}$ & $16.79 \pm 1.92^{\mathrm{bc}}$ & $58.5 \pm 3.31^{\mathrm{b}}$ \\
\hline
\end{tabular}
0.05 .

\section{References}

[1] Berova, M., Georgios Karanatsidis, Krasimira Sapundzhieva.: Folia Horticulturae Ann. 22/1:3. (2010)

[2] Boechat C.L., J.A.G. Santos, and A.M.A. Accioly.: Acta Scintiarum. Agronomy. 2013. Vol 35(2). pp 257-264. (2013)

[3] Castillo, L.E., J.J. Jimenez, dan M.A. Delgado.: Journal of Tropical and Subtropical Agroecosystems. Vol 12 pp 445-462. (2010)

[4] Castillo, L.E., Viria Bravo, Fernando Ramirez, Elba de la Cruz.: Journal of Environmental Biology, Vol 35(1) pp 43-55. (2014)

[5] Chaturvedi, M., C. Shama and M. Chaturvedi.: Research Journal of Chemical and Environmental Sciences. 2013. 1(3): 14-19. (2013)

[6] El-Hamied S.A.A.,: Journal of Agriculture and Veterinary Science (IQSR-JAVS). 7(11): 79-87. (2014)

[7] Hartatik W. and Setyorini, D.: Prosiding Seminar Nasional dan Dialog Sumber Daya Lahan Pertanian. Bogor (ID) :21-25. (2009)

[8] Jigme, N. J., P. Sutigoolabud, J. Inthasan, S. Sakhonwasee.: Journal of Organic Systems. 10(1):914. (2015)

[9] Khanom, S., A. Ahmed, S. Mahmud, and M. S. Islam.: International Journal of Agricultural Science and Research (IJASR), 2(3):116-128. (2012)

[10] Massah J.\& Azadegan B.: Africa\&Latin America, 47(1):44-50 (2016)

[11] Rai N., P. Ashiya, and D.S. Rathore.: Int. J. of Innovative Research in Science, Engineering and Technology. 3(5):12991-12998. (2014)

[12] Shin K., G.V. Diepen, W. Blok, A.H.C. Bruggen.: Crop Protection : 99: 168-176. (2017)

[13] Soeparjono, S.: Agriculture and Agricultural Science Procedia. 9:450-455. (2016)

[14] Wijayanto T., Zulfikar, M. Tufaila, A.M. Sarman, A. Zamrun.: WSEAS Transactions on Biology and Biomedicine, 3: 134-141. (2016)

[15] Xiaohou S, Min T, Ping J, Weiling C.: Water Science and Engineering, 1(4):99-106. (2008) 
[16] Motaz, A.: Start programming using Object Pascal. Vol. 2, pp. 10-11. Legally Free Computer Books, US (2013)

[17] Wasis, B. dan Fathia N.: Jurnal Ilmu Pertanian Indonesia :16(2): 123-129. (2010)

[18] Zerihun, A. And D. Haile.: Agronomy, 7(42):1-15. (2017)

[19] Zulkarnain, M., Prasetya B., dan Soemarno.: Indonesian Green Technology Journal, 2(1): 45-54.

(2013) 